\title{
An International Survey of Deep Brain Stimulation Procedural Steps
}

\author{
Aviva Abosch $^{a}$ Lars Timmermann $^{\mathrm{e}}$ Sylvia Bartley ${ }^{\mathrm{b}}$ Hans Guido Rietkerk ${ }^{f}$ \\ Donald Whiting ${ }^{c}$ Patrick J. Connolly ${ }^{d}$ David Lanctin ${ }^{a}$ Marwan I. Hariz ${ }^{g, h}$ \\ ${ }^{a}$ Department of Neurosurgery, University of Minnesota Medical Center, Minneapolis, Minn., ${ }^{\mathrm{b}}$ Medtronic \\ Corporation, Fridley, Minn., 'Department of Neurosurgery, Allegheny General Hospital, Pittsburgh, Pa., and \\ ${ }^{\mathrm{d}}$ Department of Neurology, Temple University, Philadelphia, Pa., USA; ${ }^{\mathrm{e} D e p a r t m e n t}$ of Neurology, \\ University of Cologne, Cologne, Germany; ${ }^{f}$ Vintura Consulting, Baarn, The Netherlands; ${ }^{9}$ Unit of Functional

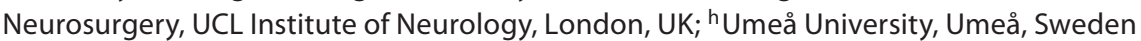

\section{Key Words}

Deep brain stimulation $\cdot$ Parkinson's disease $\cdot$ Workflow

\begin{abstract}
Background: Deep brain stimulation (DBS) surgery is standard of care for the treatment of certain movement disorders. Objective: We sought to characterize the spectrum of steps performed in DBS surgery, at centers around the world where this surgery is performed. Methods: We identified the main steps in DBS surgery workflow and grouped these 19 steps into 3 phases (preoperative, operative, and postoperative). A survey tool, informed by a pilot survey, was administered internationally by trained study personnel at high-and low-volume DBS centers. Procedural components, duration, and surgeon motivational factors were assessed. Cluster analysis was used to identify procedural and behavioral clusters. Results: One hundred eighty-five procedure workflow surveys (143 DBS centers) and 65 online surveys of surgeon motivational drivers were completed ( $45 \%$ response rate). Significant heterogeneity in technique, operative time, and surgeon motivational drivers was reported across centers. Conclusions: We provide a description of the procedural steps involved in DBS surgery and the duration of these
\end{abstract}

steps, based on an international survey. These data will enable individual surgeons and centers to examine their own experience relative to colleagues at other centers and in other countries. Such information could also be useful in comparing efficiencies and identifying workflow obstacles between different hospital environments.

Copyright $\odot 2012$ S. Karger AG, Base

\section{Background}

Deep brain stimulation (DBS) surgery has become standard of care for the surgical treatment of certain medically refractory movement disorders, including Parkinson's disease (PD), essential tremor (ET), and dystonia. The outcome of DBS for the treatment of these disorders has been reported. Specifically, results of DBS for PD have been published for randomized, controlled trials conducted in the USA [1], the UK [2], and Germany [3], demonstrating superiority in the improvement of quality of life as compared to best medical treatment [1], as well as longterm sustained efficacy of stimulation on most PD motor symptoms [4-6], for generalized and segmental dystonia [7-9] as well as for ET [10-12]. These clinically impressive

\section{KARGER}

Fax +4161306 1234

E-Mail karger@karger.ch

www.karger.com (c) 2012 S. Karger AG, Basel

1011-6125/13/0911-0001\$38.00/0

Accessible online at:

www.karger.com/sfn
Aviva Abosch, MD, $\mathrm{PhD}$

University of Minnesota, Department of Neurosurgery

D429 Mayo Memorial Building, 420 Delaware St. SE

Minneapolis, MN 55414 (USA)

E-Mail aabosch@umn.edu 
outcomes have resulted in the procedure now being performed at many centers in a variety of countries.

Although it is an established and effective treatment for movement disorders, far from all patients eligible for DBS surgery are offered this therapy. Barriers to more widespread adoption of DBS therapy include sometimes unpredictable results, diminishment of patient functional status due to disease progression, possible reluctance of clinicians to refer patients for surgery, shortage of personnel trained in DBS programming, procedural costs, and, in many centers, long waiting lists for DBS surgery. Another potential factor is patient and clinician fear of 'brain surgery', although reported complication rates are low [13]. We hypothesized that a detailed study of the procedural steps involved in DBS surgery and surgeon motivational factors might result in better information for patients and referring physicians about the nature of the procedure and what to expect during surgery, and perhaps allay some of the fears associated with the surgery. No publications have systematically addressed the various ways of performing DBS surgery. We therefore sought to characterize the current spectrum of how DBS procedures are performed in different centers and in different countries around the world. Our hypothesis was that although a detailed analysis of the procedural steps involved in DBS implantation demonstrates a large variety of different approaches, procedural 'clusters' might emerge from the analysis.

The goal of this study was to describe the spectrum of steps performed as part of DBS surgery, and to provide a detailed description of the procedural steps and their duration, at centers around the world where DBS surgery is performed. Publication of these data is intended: (1) to provide patients and referring physicians greater detail about the nature of the procedure and (2) to enable individual surgeons, movement disorder neurologists, and DBS centers to examine their own experience relative to colleagues at other centers.

\section{Methods}

Survey Formulation and Survey Tool

The main steps in the DBS surgery workflow were identified by the investigator panel, which consisted of 5 experienced functional neurosurgeons from the USA and Europe, and 1 movement disorders neurologist. These main steps - 19 in total - were then grouped into 3 phases: (1) preparation for the procedure, (2) DBS lead placement in the operating room, and (3) post-DBS lead placement procedures (fig. 1).

A survey tool was then constructed, which included questions about surgical volume, type of practice, diagnosis of the disorder being treated, equipment used, and procedural steps - such as the use of preoperative imaging, intraoperative electrophysiological confirmation, and intraoperative imaging for confirmation of electrode location. Note that neither research procedures nor procedures that were characterized by respondents as 'irregular' due to procedural mishaps (e.g. equipment broken or unavailable, staff delays, etc.) were included in our analysis.

An initial pilot study of DBS procedural flow was conducted during November and December 2009 in order to test data collection tools, project design, and data analysis methods. This pilot study was conducted during 21 DBS procedures. Study personnel were trained on the administration and completion of this survey and sent to large-volume DBS surgery centers to administer the survey and to provide feedback on its usage. This feedback - which included comments on improving the survey tool as well as identifying any additional procedural steps that might have been omitted by the investigator - was reviewed and incorporated into the final survey instrument. This survey instrument was deployed between April 2010 and March 2011, and a total of 185 surveys were completed. See online supplementary appendix 1 (for all online suppl. material, see www. karger.com/doi/10.1159/000343207) for a copy of the survey instrument.

\section{Survey Site Selection}

Survey sites were selected from around the world with the intent of recording as many operations as possible during the study period. We attempted to survey sites representing the spectrum of surgical volume - including high- and low-volume centers - in order to obtain as complete a picture as possible of daily practice.

\section{Procedure Duration}

The duration of each identified procedural step and the overall procedural time were documented by study personnel logging the start and end time of each component step.

\section{Motivational Factors}

A separate online survey was used to probe surgeon factors as potential drivers for the procedural steps of the operation. These surveys were distributed to neurosurgeons after collection of procedural data and were intended to capture general background information, assess techniques typically employed for key procedural steps ( 9 in total), and facilitate an understanding of the motivations behind the use of a particular technique. Decision drivers were scored from 1 to 5 , with 1 representing the 'least applicable' and 5 the 'most applicable' motivating factor (online suppl. appendix 2). The surgeon factors surveyed were first identified by the investigator panel, and pursued in a pilot study.

In addition to decision factors related to selection of the procedural technique, the questionnaire contained questions aimed at understanding the background of the surgeon and other motivational and behavioral factors. The theoretical foundation for the questionnaire is derived from work by Barbuto and Scholl, which operationalized the assessment of individual behavior [14]. Analysis of the pilot study questionnaire results was used to finalize the wording of the questionnaire, which contained 30 questions addressing critical motivational factors among a larger population of DBS neurosurgeons. Questions about motivation included whether or not the surgeon respondent prioritized the research mission over clinical care, or vice versa. 


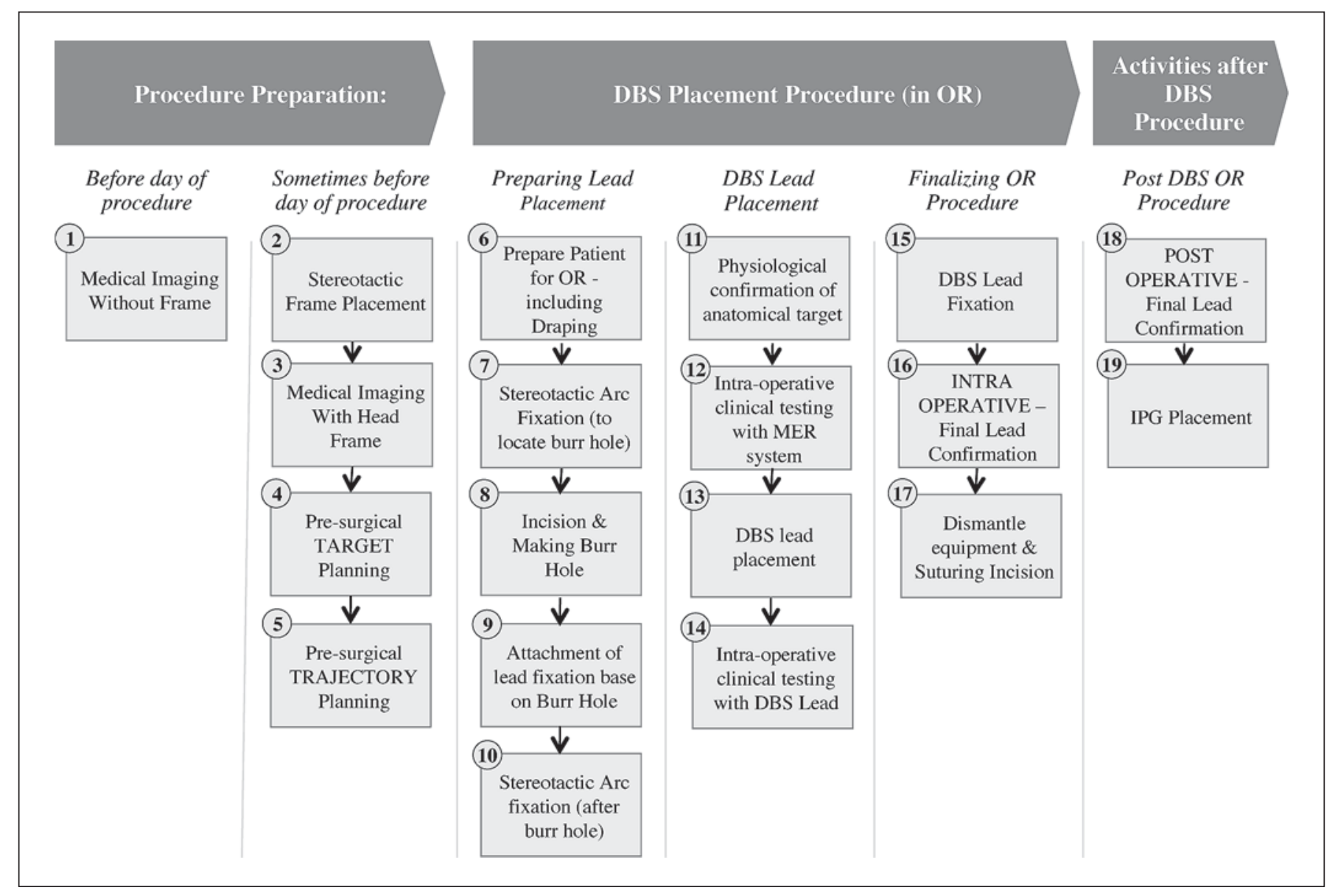

Fig. 1. DBS surgical procedure, broken down into 19 component steps.

\section{Data Analysis}

Data compilation and reporting were performed using Excelbased tools (Microsoft, Redmond, Wash., USA). Additionally, Clustan $^{\mathrm{TM}}$, a statistical software program, was used to identify procedural and behavioral clusters. Clustan supports the applied analysis process of partitioning larger datasets into homogeneous subsets by grouping closely related cases into tight clusters. These clusters can then be used to construct the underlying model, for segmentation analysis and for exemplification [15].

\section{Results}

\section{Summary Statistics}

A total of 185 procedure workflow surveys were completed, representing 143 DBS surgery centers (fig. 2). Additionally, surgeons who participated in completion of the procedure workflow survey were invited to fill out the online surgeon motivational driver survey. Sixty-five online surveys of surgeon motivational drivers were ulti-

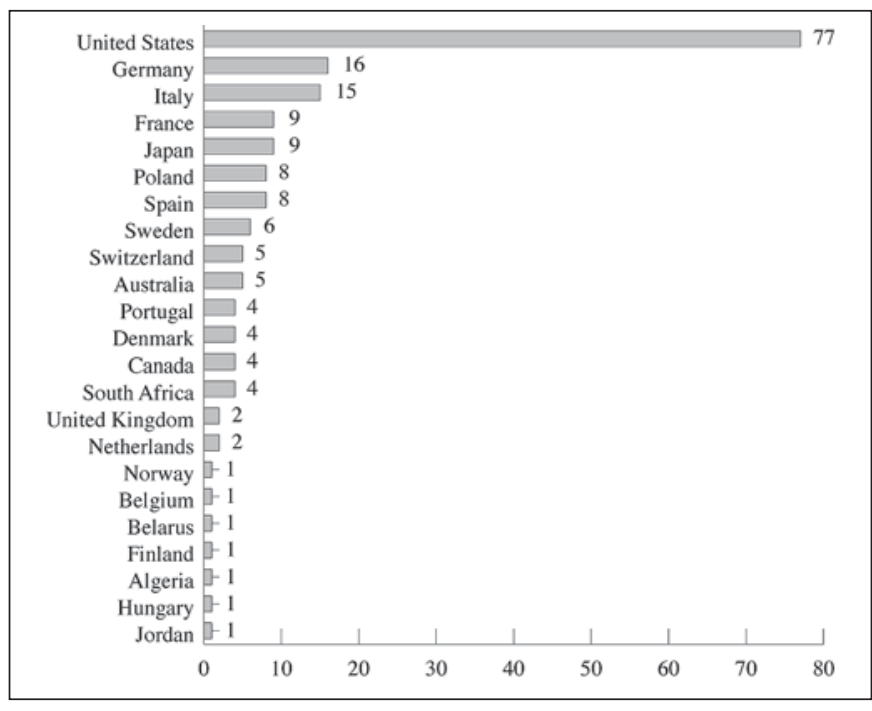

Fig. 2. Number of survey respondents by location of the DBS cen$\operatorname{ter}(\mathrm{n}=185)$. 


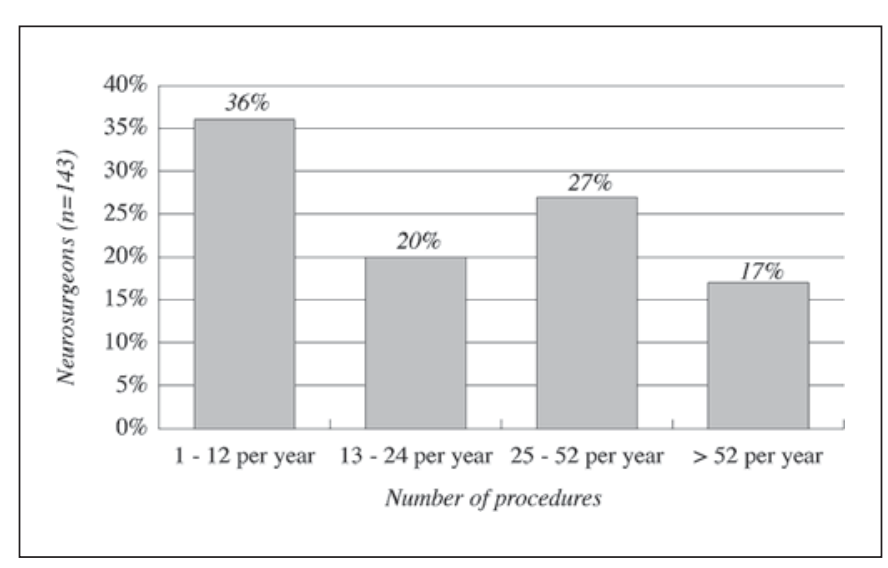

Fig. 3. Reported annual volume of DBS surgeries for participating centers $(n=143)$.

mately completed. Respondents came from many different countries, including the USA, Canada, Europe, Japan, South Africa, and Jordan. A total of 146 surgeons participated in the survey completion. Additionally, the online Motivational Drivers survey was completed by $45 \%$ of potential responders $(n=65)$.

Survey responses indicated that $36 \%$ of neurosurgeons performed fewer than 1 procedure/month, 56\% performed fewer than 2 procedures/month, $27 \%$ performed 2-4 procedures/month, and $17 \%$ performed an average of more than 4 procedures/month (fig. 3).

DBS targets selected for each indication are shown in figure 4 , with the majority of procedures carried out for the treatment of PD $(n=131)$. Interestingly, respondents indicated that $94 \%$ of surgeries for PD targeted STN, 3\% targeted GPi, and 3\% targeted VIM. Of the procedures performed in patients with ET ( $\mathrm{n}=30), 29(97 \%)$ targeted VIM and 1 (3\%) targeted STN (fig. 4).

\section{Procedural Mapping}

Survey responses were grouped, by diagnosis of disorder treated, into categories for PD (133), ET $(n=31)$, and dystonia (21). In each of these categories, 2,1 , and 2 cases, respectively, were reported as research cases and excluded from further analysis. There were a total of 48 unilateral and 137 bilateral DBS procedures reported. Within the former category, 42 surgeries were deemed 'regular'; within the latter category, 121 procedures were deemed 'regular' - meaning nonresearch procedures not characterized by the occurrence of procedural irregularities (e.g. equipment problems, atypical procedural delays, and/or adverse events).

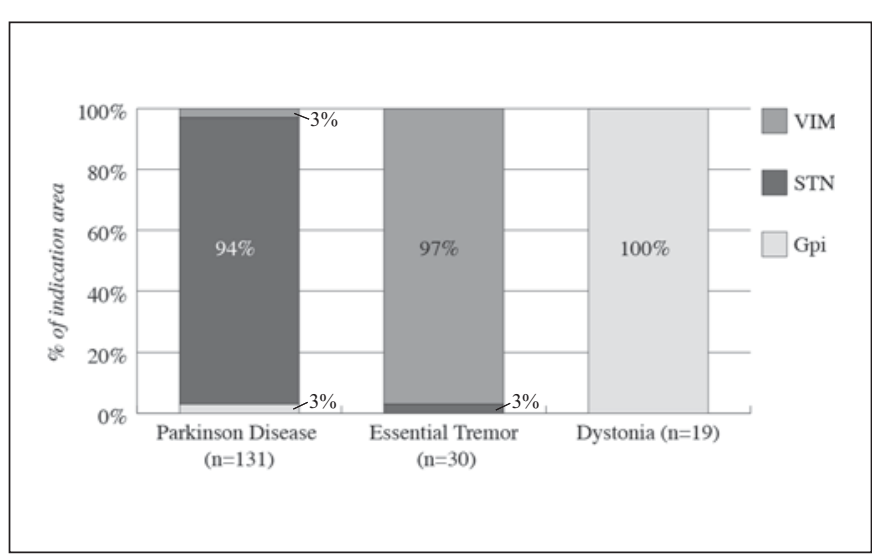

Fig. 4. DBS target used per indication $(n=180$, excluding research cases).

Of the total number of surgeries performed for PD (131), 7\% were carried out under general endotracheal anesthesia (GETA) versus 56\% of surgeries performed for the treatment of dystonia (fig. 5a). The use of conscious sedation during procedures was not surveyed, nor was the rationale for the selection of a particular method of anesthesia. GETA was not used in a single operation for ET. In the case of surgeries for PD, a difference was identified in the use of GETA between large-volume centers characterized by an annual volume of greater than 52 DBS cases/year (26\% used GETA) and small-volume centers characterized by a volume of fewer than 12 cases/year (0\% used GETA; fig 5b). Surgeries using GETA lasted on average 3:53 versus 4:00 $\mathrm{h}$ for surgery without GETA (not statistically significant).

A heat map depicting the percentage of users for each individual technique within the various procedural steps is provided in figure 6 . The majority of respondents $(69 \%, \mathrm{n}=125)$ obtained stereotactic CT imaging of patients in a headframe and co-registered preoperative MRI images to this stereotactic CT. Approximately 83\% $(\mathrm{n}=149)$ used a combination of AC-PC-based consensus targeting and direct visualization of target structures $(79 \%, \mathrm{n}=142)$. The majority of respondents also reported using microelectrode recording to obtain physiological confirmation of the target structure $(83 \%, n=149)$. Fluoroscopy was used intraoperatively to confirm lead location by $63 \%$ of respondents, and postoperative CT was used for this purpose by $70 \%$. Postoperative MRI was used in the minority of cases to confirm lead location $(14 \%, \mathrm{n}=22)$. 

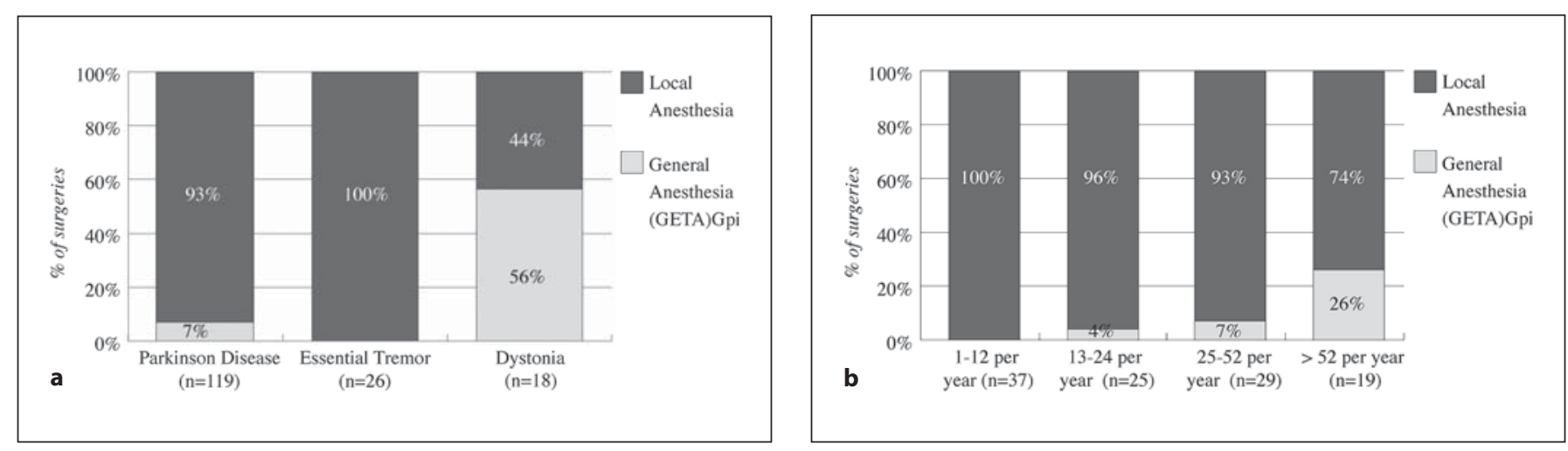

Fig. 5. a Type of anesthesia used for DBS surgeries, by indication. Note that only nonresearch cases $(n=180)$ are included, and 17 cases for which anesthesia type was not recorded are excluded. b Type of anesthesia used for DBS surgeries for PD, by DBS center volume $(\mathrm{n}=110)$.

\section{Procedural Clusters}

Five clusters involving component steps of the overall DBS surgery procedure were identified using Clustan statistical software (fig. 7). These clusters were geographically distributed into predominantly Italian/Polish (cluster 3), German (cluster 4), French/Japanese (cluster 5), and US clusters (clusters 1 and 2; fig. 7; table 1). Cluster 1, representing the USA, Australia, and Spain, was the largest cluster $(n=45)$ and was characterized primarily by the use of a mini-stereotactic frame (25\%) and the absence of intraoperative confirmation of lead location (80\%). Cluster 2 was comprised of a second US procedural category and Canada. The key difference between clusters 1 and 2 is that the latter was characterized by the use of intraoperative lead confirmation (95\%), primarily via fluoroscopy. Cluster 4, representing Germany, comprised the smallest cluster $(n=9)$ and was characterized by the use of the Riechert-Mundiger or RM frame (50\%) for stereotaxy, and the use of a mini-plate for DBS lead fixation (54\%). Cluster 5 represented France, Japan, and the Nordic countries. This cluster was characterized by the use of MRI-based stereotaxy (79\%) and X-ray for intraoperative lead confirmation (54\%).

\section{Duration of Procedure and Component Steps}

For bilateral procedures in which all steps took place during a single operative day, the total procedural time for steps 2-17 was longest for cluster 3 (Italian/Polish; $\mathrm{n}=14$ ), at 7:02 $\mathrm{h}$, by a considerable amount, and cluster 1 (USA; $\mathrm{n}=14$ ) was the shortest at 5:05 h (table 2). Fortynine percent of DBS procedures involved performing all 4 component surgeries (bilateral DBS electrode place-
Table 1. Geographic distribution of the 5 identified procedural clusters ( $\mathrm{n}=146 ; 1$ case per surgeon)

\begin{tabular}{|c|c|c|c|c|c|}
\hline Countries & $\begin{array}{l}\text { Cluster } 1 \\
(\mathrm{n}=46)\end{array}$ & $\begin{array}{l}\text { Cluster } 2 \\
(\mathrm{n}=35)\end{array}$ & $\begin{array}{l}\text { Cluster } 3 \\
(\mathrm{n}=33)\end{array}$ & $\begin{array}{l}\text { Cluster } 4 \\
(\mathrm{n}=9)\end{array}$ & $\begin{array}{l}\text { Cluster } 5 \\
(\mathrm{n}=22)\end{array}$ \\
\hline USA & 70 & 71 & & & \\
\hline Italy & 2 & & 30 & & 5 \\
\hline Germany & & 3 & 3 & 89 & 9 \\
\hline France & & & 3 & & 36 \\
\hline Japan & 2 & 3 & 3 & & 23 \\
\hline Spain & 9 & 6 & 3 & & \\
\hline Poland & 2 & & 15 & & \\
\hline Sweden & 2 & 3 & & & 9 \\
\hline Canada & 2 & 6 & & & 5 \\
\hline Australia & 7 & 3 & & & \\
\hline Switzerland & & & 6 & 11 & \\
\hline Portugal & & & 9 & & \\
\hline South Africa & & & 9 & & \\
\hline UK & 2 & & & & 5 \\
\hline The Netherlands & & & 6 & & \\
\hline Denmark & 2 & 3 & & & \\
\hline Hungary & & & 3 & & \\
\hline Jordan & & & & & 5 \\
\hline Belgium & & & 3 & & \\
\hline Norway & & 3 & & & \\
\hline Finland & & & & & 5 \\
\hline Algeria & & & 3 & & \\
\hline Belarus & & & 3 & & \\
\hline Total & 100 & 100 & 100 & 100 & 100 \\
\hline
\end{tabular}

Values are percents. 


\begin{tabular}{|c|c|c|c|c|c|c|}
\hline $\begin{array}{l}\text { Step } \\
\text { No. }\end{array}$ & $\begin{array}{l}\text { Step } \\
\text { Description }\end{array}$ & $\begin{array}{l}\text { Most frequently } \\
\text { used technique }\end{array}$ & & & $\begin{array}{l}\text { Least frequently } \\
\text { used technique }\end{array}$ & $\begin{array}{l}\text { Other/ } \\
\text { Unknown }\end{array}$ \\
\hline 1 & $\begin{array}{l}\text { Medical Imaging - } \\
\text { Without Headframe }\end{array}$ & $\begin{array}{c}\text { MRI } \\
83 \%(n=149)\end{array}$ & $\begin{array}{c}\text { CT } \\
3 \%(n=5)\end{array}$ & $\begin{array}{c}\text { Both MRI \& CT } \\
\text { (without frame) } \\
2 \%(n=4)\end{array}$ & & $12 \%(\mathrm{n}=22)$ \\
\hline 2 & $\begin{array}{l}\text { Stereotactic Frame } \\
\text { Placement }\end{array}$ & $\begin{array}{c}\text { Leksell (Elekta) } \\
51 \%(n=92)\end{array}$ & $\begin{array}{c}\text { CRW } \\
29 \%(n=52)\end{array}$ & $\underset{7 \%(n=12)}{\mathbf{R M}}$ & $\begin{array}{c}\text { ZD } \\
1 \%(n=1)\end{array}$ & $13 \%(n=23)$ \\
\hline 3 & $\begin{array}{l}\text { Medical Imaging - } \\
\text { With Headframe }\end{array}$ & $\begin{array}{c}\text { CT Stereotactic } \\
69 \%(n=125)\end{array}$ & $\begin{array}{l}\text { MRI Stereotactic } \\
22 \%(n=40)\end{array}$ & $\begin{array}{c}\text { Both MRI \& CT } \\
\text { Stereotactic } \\
4 \%(n=7) \\
\end{array}$ & & $4 \%(n=8)$ \\
\hline 4 & $\begin{array}{l}\text { Pre-Surgical } \\
\text { TARGET Planning }\end{array}$ & $\begin{array}{c}\text { Combi of AC/PC based } \\
\text { \& direct visual. } \\
79 \%(n=142)\end{array}$ & $\begin{array}{c}\text { AC/PC based with } \\
\text { respect to } \mathbf{M C P} \\
17 \%(n=30)\end{array}$ & $\begin{array}{c}\text { Direct visualization } \\
\text { targeting } \\
4 \%(n=7)\end{array}$ & & $1 \%(\mathrm{n}=1)$ \\
\hline 5 & $\begin{array}{l}\text { Pre-Surgical } \\
\text { TRAJECTORY } \\
\text { Planning } \\
\end{array}$ & $\begin{array}{c}\text { Combi of AC/PC based } \\
\text { \& direct visual. } \\
69 \%(n=124)\end{array}$ & $\begin{array}{c}\text { AC/PC based with } \\
\text { respect to } \mathrm{MCP} \\
10 \%(n=18)\end{array}$ & $\begin{array}{c}\text { Direct visualization } \\
\text { targeting } \\
8 \%(n=14) \\
\end{array}$ & & $13 \%(n=24)$ \\
\hline 6 & $\begin{array}{l}\text { Preparing Patient in/ } \\
\text { for OR, including } \\
\text { Draping }\end{array}$ & $\begin{array}{c}\text { Using } 1 \text { Large Drape } \\
64 \%(n=115)\end{array}$ & $\begin{array}{l}\text { Using small pieces } \\
29 \%(n=52)\end{array}$ & & & $7 \%(\mathrm{n}=13)$ \\
\hline 8 & $\begin{array}{l}\text { Incision \& Making } \\
\text { Burr Hole }\end{array}$ & $\begin{array}{c}\text { Curved } \\
56 \%(n=100)\end{array}$ & $\begin{array}{c}\text { Straight } \\
34 \%(n=62)\end{array}$ & $\begin{array}{c}\text { One incision cross both } \\
\text { hemisph. } \\
8 \%(n=15)\end{array}$ & & $2 \%(\mathrm{n}=3)$ \\
\hline 8B & Specify Burr Hole & $\begin{array}{c}14 \mathbf{~ m m} \\
88 \%(n=158)\end{array}$ & $\begin{array}{c}12 \mathbf{m m} \\
3 \%(n=6)\end{array}$ & $\begin{array}{c}\mathbf{6} \mathbf{~ m m} \\
2 \%(n=4)\end{array}$ & & $7 \%(\mathrm{n}=12)$ \\
\hline 9 & $\begin{array}{l}\text { Attachment of Lead } \\
\text { Fixation Base (on } \\
\text { burr hole) }\end{array}$ & $\begin{array}{c}\text { Medtronic Stimloc } \\
68 \%(n=123)\end{array}$ & $\begin{array}{c}\text { Medtronic Cap } \\
12 \%(n=21)\end{array}$ & $\begin{array}{c}\text { None (no fixation base } \\
\text { used) } \\
12 \%(n=21)\end{array}$ & & $8 \%(\mathrm{n}=15)$ \\
\hline 11 & $\begin{array}{l}\text { Physiological } \\
\text { confirmation of } \\
\text { anatomical target }\end{array}$ & $\begin{array}{c}\text { Micro-electrode } \\
\text { recording set-up } \\
83 \%(n=149) \\
\end{array}$ & $\begin{array}{c}\text { No confirmation } \\
\text { localization } \\
8 \%(n=14) \\
\end{array}$ & $\begin{array}{c}\text { Impedance probe } \\
\text { (for target confirmation) } \\
2 \%(n=4)\end{array}$ & $\begin{array}{c}\text { Using LFP } \\
\text { Techniques } \\
1 \%(n=1)\end{array}$ & $7 \%(n=12)$ \\
\hline 12 & $\begin{array}{l}\text { Intra Operative } \\
\text { Clinical Testing } \\
\text { (with MER system) }\end{array}$ & $\begin{array}{c}\text { Macro Stimulation } \\
\text { (using MER Electr.) } \\
62 \%(n=112)\end{array}$ & $\begin{array}{c}\text { N/A - no testing before } \\
\text { DBS Lead } \\
26 \%(n=46)\end{array}$ & & & $12 \%(n=22)$ \\
\hline 13 & DBS Lead Placement & $\begin{array}{c}\text { Using a Guiding } \\
\text { Cannula } \\
62 \%(n=111)\end{array}$ & $\begin{array}{c}\text { NOT using a Guiding } \\
\text { Cannula } \\
37 \%(n=67)\end{array}$ & & & $1 \%(\mathrm{n}=2)$ \\
\hline 14 & $\begin{array}{l}\text { Intra Operative } \\
\text { Testing with DBS } \\
\text { Lead }\end{array}$ & $\begin{array}{c}\text { Macro Stimulation } \\
\text { (using DBS Lead) } \\
51 \%(n=92)\end{array}$ & $\begin{array}{c}\text { N/A - no testing with } \\
\text { DBS Lead } \\
45 \%(n=81)\end{array}$ & & & $4 \%(n=7)$ \\
\hline 15 & DBS Lead Fixation & $\begin{array}{c}\text { Medtronic Stimloc } \\
70 \%(n=125)\end{array}$ & $\begin{array}{c}\text { Medtronic Cap } \\
15 \%(n=27)\end{array}$ & $\begin{array}{c}\text { Bone cement } \\
5 \%(n=9)\end{array}$ & $\begin{array}{l}\text { Mini plate } \\
7 \%(n=12)\end{array}$ & $3 \%(\mathrm{n}=6)$ \\
\hline 16 & $\begin{array}{l}\text { INTRA OPERATIVE } \\
\text { - Final Lead } \\
\text { Confirmation }\end{array}$ & $\begin{array}{c}\text { Fluoroscopy } \\
45 \%(n=81)\end{array}$ & $\begin{array}{c}\text { N/A - No Lead } \\
\text { Confirmation Done } \\
22 \%(n=39)\end{array}$ & $\underset{12 \%(n=22)}{\mathbf{X}-\mathbf{R a y}}$ & $\underset{6 \%(n=10)}{\mathbf{C T}}$ & $16 \%(n=28)$ \\
\hline 18 & $\begin{array}{l}\text { POST OPERATIVE - } \\
\text { Final Lead } \\
\text { Confirmation }\end{array}$ & $\begin{array}{c}\text { CT } \\
61 \%(n=109)\end{array}$ & $\begin{array}{c}\text { N/A - No Lead } \\
\text { Confirmation Done } \\
13 \%(n=24)\end{array}$ & $\begin{array}{c}\text { MRI } \\
12 \%(n=22)\end{array}$ & $\begin{array}{l}\text { Fluoroscopy } \\
4 \%(n=8)\end{array}$ & $9 \%(\mathrm{n}=17)$ \\
\hline 19 & IPG Implant & $\begin{array}{c}\text { Dual Channel IPG } \\
63 \%(n=113)\end{array}$ & $\begin{array}{c}\text { One or Two Single } \\
\text { Channels } \\
29 \%(n=52)\end{array}$ & & & $8 \%(\mathrm{n}=15)$ \\
\hline 19B & $\begin{array}{l}\text { Specify Location of } \\
\text { IPG }\end{array}$ & $\begin{array}{c}\text { Subclavicular } \\
83 \%(n=149)\end{array}$ & $\begin{array}{l}\text { Abdominal } \\
10 \%(\mathrm{n}=18)\end{array}$ & & & $7 \%(n=13)$ \\
\hline
\end{tabular}

Fig. 6. Heat map of techniques used for each DBS procedural step. Red indicates that more than $65 \%$ of surgeons employed a particular technique, orange indicates usage of a technique by $35-64 \%$ of surgeons, yellow indicates usage by $10-34 \%$, and white indicates usage by fewer than $10 \%$ of surgeons (colors are shown online only). 


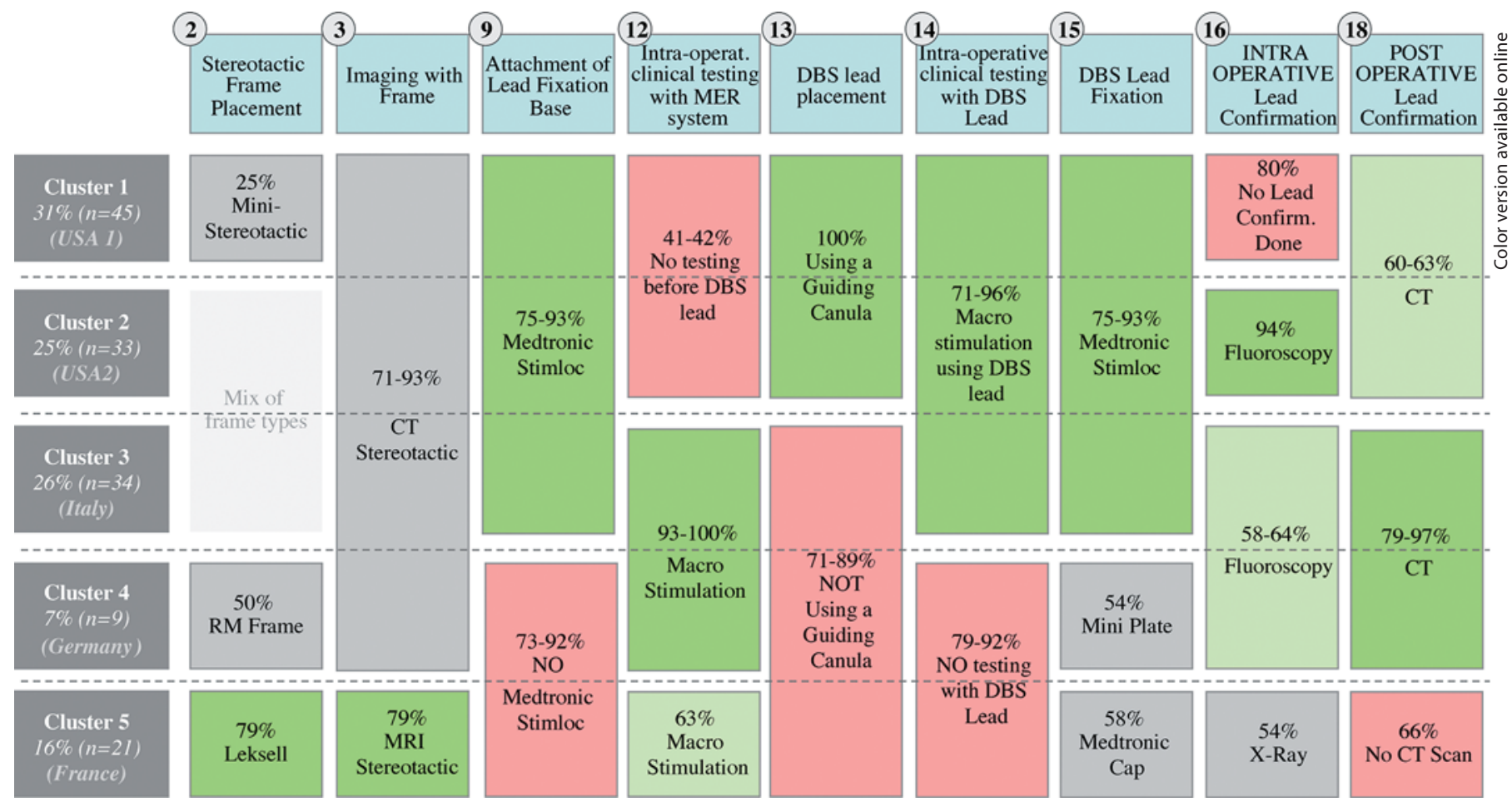

Fig. 7. Key differences between DBS surgery procedural clusters.

Table 2. Average surgical procedure duration per cluster category

a Duration of OR procedure (steps 6-17)

\begin{tabular}{|c|c|c|c|c|c|c|}
\hline Cluster & 1 & 2 & 3 & 4 & 5 & Overall average \\
\hline \multicolumn{7}{|c|}{ OR duration, $h$} \\
\hline Bilateral & $3: 02(\mathrm{n}=13)$ & $3: 21(\mathrm{n}=15)$ & $4: 09(n=16)$ & $3: 22(\mathrm{n}=8)$ & $3: 19(\mathrm{n}=5)$ & $3: 30(n=57)$ \\
\hline Unilateral & $1: 54(\mathrm{n}=7)$ & $2: 35(\mathrm{n}=15)$ & $2: 27(\mathrm{n}=4)$ & $(\mathrm{n}=0)$ & $(\mathrm{n}=0)$ & $2: 23(\mathrm{n}=26)$ \\
\hline
\end{tabular}

b Duration of the total DBS procedure (steps 2-17)

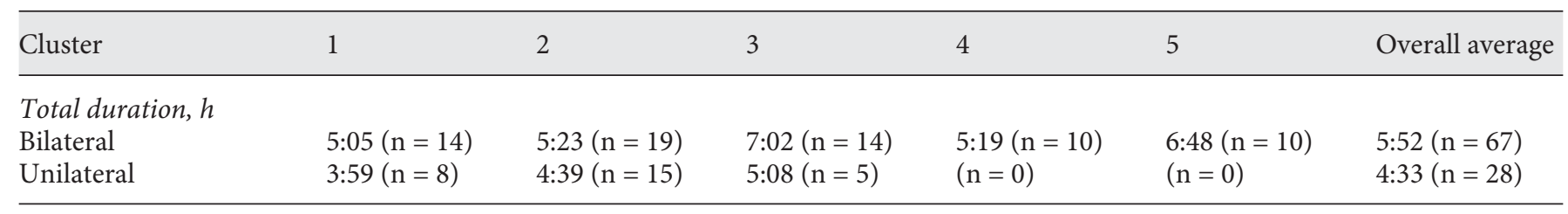


Table 3. Duration of the DBS surgery procedure per surgeon motivational profile

\begin{tabular}{|c|c|c|c|}
\hline $\begin{array}{l}\text { Motiva- } \\
\text { tional } \\
\text { profile } \\
\text { No. }\end{array}$ & Short profile description & $\begin{array}{l}\text { Total } \\
\text { duration } \\
\text { (steps } \\
1-19), \mathrm{h}\end{array}$ & $\begin{array}{l}\text { Net } \\
\text { duration } \\
\text { (steps } \\
2-17), \mathrm{h}\end{array}$ \\
\hline 1 & $\begin{array}{l}\text { High motivation based on scientific } \\
\text { inquiry }\end{array}$ & $5: 52$ & $4: 59$ \\
\hline 2 & $\begin{array}{l}\text { High DBS volume; highly oriented } \\
\text { toward patient care }\end{array}$ & $5: 13$ & $4: 22$ \\
\hline 3 & $\begin{array}{l}\text { High DBS volume; evincing a lesser } \\
\text { orientation towards patient care }\end{array}$ & $6: 31$ & $4: 51$ \\
\hline 4 & $\begin{array}{l}\text { Minimal motivation by scientific } \\
\text { inquiry, low annual DBS surgery } \\
\text { volume, and high non-DBS surgical } \\
\text { volume }\end{array}$ & $5: 18$ & $4: 10$ \\
\hline
\end{tabular}

ment + bilateral implantable pulse generator/extension cable placement) on a single operative day (fig. 8). Only $13 \%$ of cases reported by US sites were not staged - in contrast to cases reported by European sites, where the majority (66\%) of procedures where not staged (fig. 8).

The correlation between greater surgeon DBS volume and shorter duration of procedure is depicted graphically in figure 9. As expected, a statistically significant negative correlation was observed between DBS volume and procedure length $(-0.526, \mathrm{p}=0.001)$. The average time for completing steps $2-17$ on a single operative date was $8: 45 \mathrm{~h}$, and the shortest duration was $3: 50 \mathrm{~h}$. Specific information about time requirements for sequential microelectrode recordings versus multiple simultaneous microelectrode recordings was not obtained.

\section{Surgeon Motivational Factors}

A total of 65 surgeons responded to the online survey of motivational factors, intended to determine if these factors correlated with the use of any particular procedural steps or clusters. Four different motivational profiles were identified among respondents: (1) surgeons who reported high motivation based on scientific inquiry, (2) surgeons with a high DBS volume who were highly oriented toward patient care, (3) surgeons with a high DBS volume who evinced a lesser orientation towards patient care, and (4) surgeons who were minimally motivated by scientific inquiry and had a low annual DBS surgery volume and a high non-DBS surgical volume (table 3).

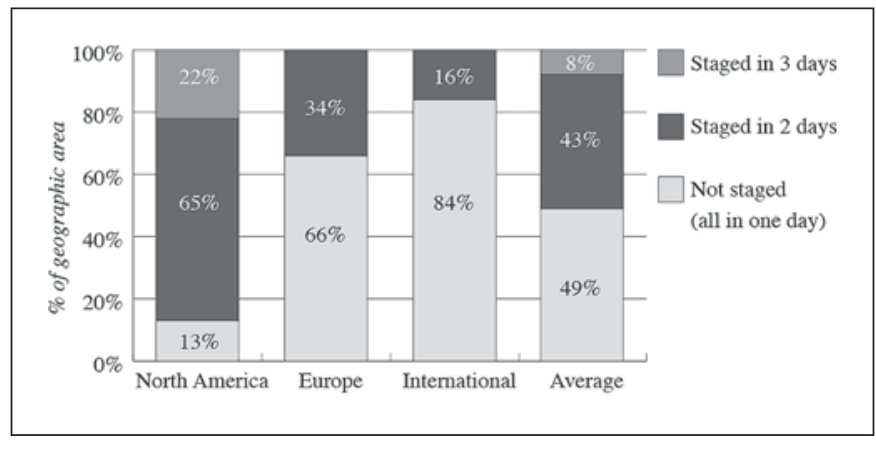

Fig. 8. Staging of component steps of DBS procedure by geographic region.

\section{Discussion}

We have provided a detailed description of the procedural steps involved in DBS surgery and the duration of these steps, at centers around the world where DBS surgery is performed. Our hope is that these data will enable individual surgeons and centers to examine their own experience relative to colleagues at other centers and in other countries. No collection of any outcome data - including accuracy of lead placement, clinical efficacy, and adverse events - was intended or obtained in this survey-based study. Rather, the information presented here could be useful for individual surgeons starting out in this field, to gauge their individual time management on a step-by-step basis relative to other practitioners around the world. Such information could also be useful in comparing efficiencies and identifying workflow obstacles between different hospital environments.

Additionally, our analysis revealed profound differences in the procedural workflow between US and European DBS centers, including the fact that procedures occurring in the USA were more likely to be staged than those at European centers, the overall duration of procedures occurring in the USA was shorter than those carried out in European centers, and the majority of procedures in the USA involved the use of a guide canula for placement of the DBS electrode, whereas the majority of procedures performed in Europe did not (fig. 7). It is not clear whether such procedural differences might contribute to differences in patient outcome, and this issue should be considered when reviewing outcome reports.

The use of GPi as a DBS target for the treatment of PD was minimal in our survey. This is interesting since our survey was performed after the publication of results of a 


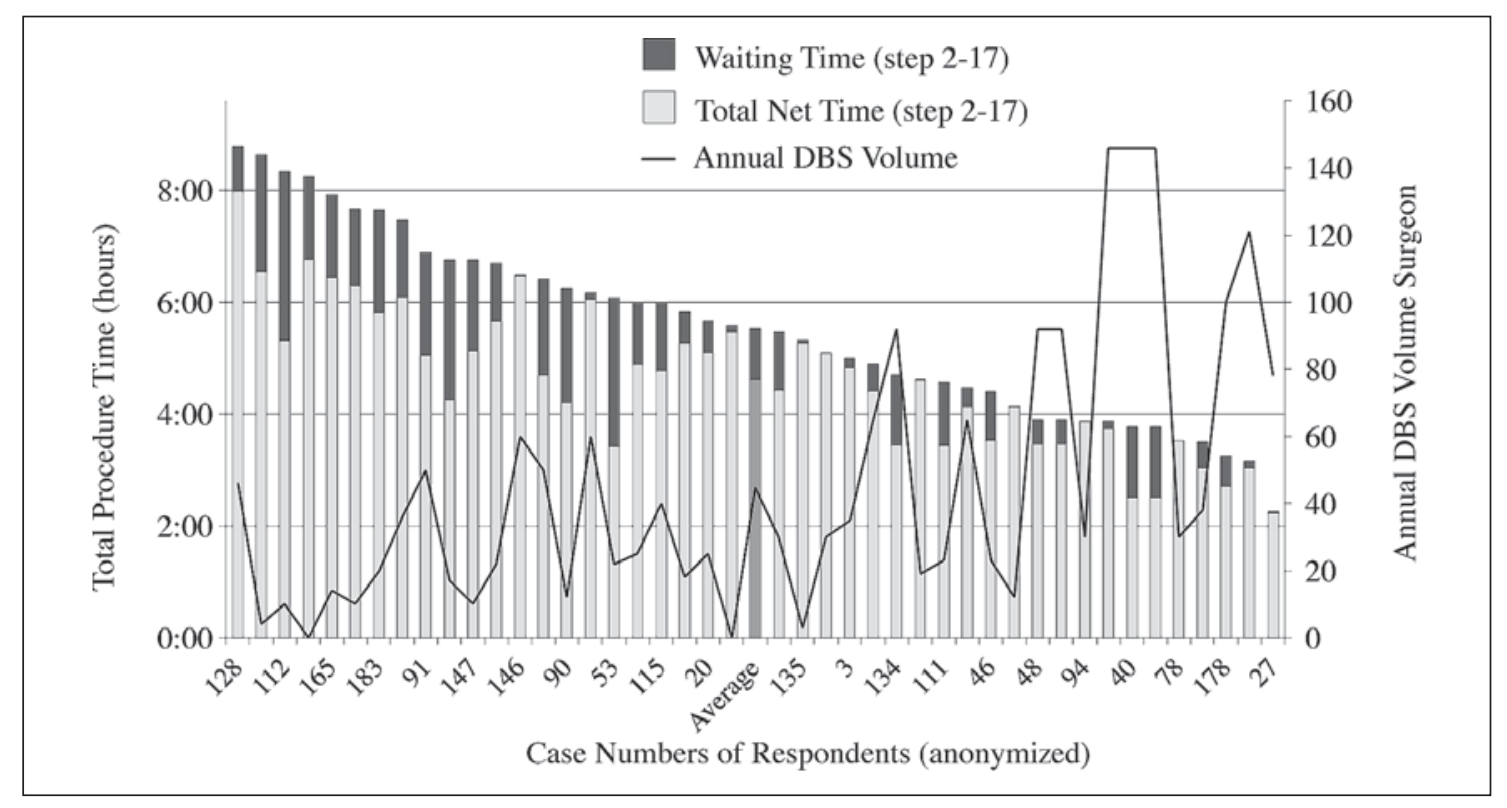

Fig. 9. Duration of DBS procedure (from patient preparation in operating room through closing of incision) and total extra-operative wait time, relative to annual surgeon DBS volume.

large-scale, randomized comparison between GPi and STN DBS for the treatment of PD - a study that demonstrated comparable efficacy for these two targets [16], although with a slightly higher risk of postoperative depression in patients receiving STN DBS. The decision to target STN may be informed by several case series that found the benefit of GPi to attenuate over time [17-20].

One very interesting aspect of this study is the different motivational 'drivers' for neurosurgeons performing DBS. Existing published reports about the outcome of DBS surgery are predominantly based on the experience of neurosurgeons at high-volume DBS centers. The procedure, as performed by the larger population of neurosurgeons implanting DBS devices, is possibly quite different and led to our decision to survey low-volume centers as well. The total procedural time was clearly different between high-volume and low-volume DBS implanting centers. Although patient outcome was not assessed in our study, theoretically the risk of infection and other procedure-related complications, as well as patient discomfort, may increase with increasing operative time. It is interesting to note that wait times were longest for surgeons with lower DBS surgery volumes, perhaps reflecting decreased institutional commitment to lower-volume centers, efficiencies of scale associated with larger-volume centers, or greater care taken at lower-volume centers.

International DBS Procedure Survey
Only $13 \%$ of cases reported by US sites were not staged - in contrast to cases reported by European sites, where the majority of procedures where not staged. This finding might reflect differences in US and European physician practice patterns, motivated by differences in clinical rationale and/or insurance reimbursement practices. A correlation between increasing length-of-stay and complication rates has been described in the literature $[21,22]$. The possibility that unstaged procedures might be associated with a longer length of stay, could have an impact on the decision to stage the procedure in the USA, where there is increasing scrutiny placed on complication rates [23].

It should be noted that $3.2 \%$ of DBS procedures for ET targeted the STN - a target that is not currently approved for this indication by the US Food and Drug Administration. However, this 3.2\% represents only one procedure at one surgical center. There is currently limited evidence supporting the use of STN-targeted DBS for ET [24, 25].

\section{Caveats and Pitfalls}

This was a survey-based study, with surveys completed by trained study personnel. It was performed prospectively and survey responses were not obtained directly from operative databases or anesthetic records. The response rate to the survey about motivational drivers

Stereotact Funct Neurosurg 2013;91:1-11 
within our study, although significantly higher than most physician survey studies [26], was still only $50 \%$, which means that responder bias could have affected the study results.

It should be noted that any given surgeon's 'standard' procedure can change over time and can vary based on the indication for surgery and due to various patient-specific factors.

Finally, it is worth reiterating that the data reported here do not imply that the procedural categories and times reported for each procedural step are appropriate or should be viewed as 'benchmarks'. Nor was this study intended to evaluate which procedural pathways are associated with the optimal benefit-to-side effect profile.

\section{Future Work}

With the identification of different procedural clusters within the overall DBS surgical procedure, it might be possible to identify key differences between procedures and construct prospective investigations aimed at evalu- ating differences in patient outcomes between these procedural clusters. Such an analysis, however, will depend on important factors in addition to the surgical procedure, per se - such as patient selection for DBS for a given diagnosis, and postoperative programming of stimulation and management of medications.

\section{Acknowledgements}

The Unit of Functional Neurosurgery (UCL) is supported by the UK Parkinson Appeal, the Edmond J. Safra Philanthropic Foundation, and the Monument Trust.

\section{Disclosure Statement}

Dr. Abosch has received honoraria from Medtronic for consulting and is the recipient of an investigator-initiated research grant from Medtronic. Dr. Hariz has received honoraria and travel expenses from Medtronic for speaking at meetings and for ad hoc advice.

\section{References}

$\checkmark 1$ Weaver FM, Follett K, Stern M, Hur K, Harris C, Marks WJ Jr, Rothlind J, Sagher O, Reda D, Moy CS, Pahwa R, Burchiel K, Hogarth P, Lai EC, Duda JE, Holloway K, Samii A, Horn S, Bronstein J, Stoner G, Heemskerk J, Huang GD: Bilateral deep brain stimulation vs. best medical therapy for patients with advanced Parkinson disease: a randomized controlled trial. JAMA 2009;301: $63-73$.

$>2$ Williams A, Gill S, Varma T, Jenkinson C, Quinn N, Mitchell R, Scott R, Ives N, Rick C, Daniels J, Patel S, Wheatley K: Deep brain stimulation plus best medical therapy versus best medical therapy alone for advanced Parkinson's disease (PD SURG trial): a randomised, open-label trial. Lancet Neurol 2010;9:581-591.

$\checkmark 3$ Deuschl G, Schade-Brittinger C, Krack P, Volkmann J, Schafer H, Botzel K, Daniels C, Deutschlander A, Dillmann U, Eisner W, Gruber D, Hamel W, Herzog J, Hilker R, Klebe S, Kloss M, Koy J, Krause M, Kupsch A, Lorenz D, Lorenzl S, Mehdorn HM, Moringlane JR, Oertel W, Pinsker MO, Reichmann H, Reuss A, Schneider GH, Schnitzler A, Steude U, Sturm V, Timmermann L, Tronnier V, Trottenberg T, Wojtecki L, Wolf E, Poewe W, Voges J: A randomized trial of deep-brain stimulation for Parkinson's disease. N Engl J Med 2006;355:896-908.
-4 Herzog J, Volkmann J, Krack P, Kopper F, Potter M, Lorenz D, Steinbach M, Klebe S, Hamel W, Schrader B, Weinert D, Muller D, Mehdorn HM, Deuschl G: Two-year followup of subthalamic deep brain stimulation in Parkinson's disease. Mov Disord 2003;18: 1332-1337.

5 Rodriguez-Oroz MC, Obeso JA, Lang AE, Houeto JL, Pollak P, Rehncrona S, Kulisevsky J, Albanese A, Volkmann J, Hariz MI, Quinn NP, Speelman JD, Guridi J, Zamarbide I, Gironell A, Molet J, PascualSedano B, Pidoux B, Bonnet AM, Agid Y, Xie J, Benabid AL, Lozano AM, Saint-Cyr J, Romito L, Contarino MF, Scerrati M, Fraix V, Van Blercom N: Bilateral deep brain stimulation in Parkinson's disease: a multicentre study with 4 years follow-up. Brain 2005; 128 : 2240-2249.

6 Merola A, Zibetti M, Angrisano S, Rizzi L, Ricchi V, Artusi CA, Lanotte M, Rizzone MG, Lopiano L: Parkinson's disease progression at 30 years: a study of subthalamic deep brain-stimulated patients. Brain 2011;134: 2074-2084.

7 Vidailhet M, Vercueil L, Houeto JL, Krystkowiak P, Lagrange C, Yelnik J, Bardinet E, Benabid AL, Navarro S, Dormont D, Grand S, Blond S, Ardouin C, Pillon B, Dujardin K, Hahn-Barma V, Agid Y, Destee A, Pollak P: Bilateral, pallidal, deep-brain stimulation in primary generalised dystonia: a prospective 3 year follow-up study. Lancet Neurol 2007; 6:223-229.
8 Kupsch A, Benecke R, Muller J, Trottenberg T, Schneider GH, Poewe W, Eisner W, Wolters A, Muller JU, Deuschl G, Pinsker MO, Skogseid IM, Roeste GK, Vollmer-Haase J, Brentrup A, Krause M, Tronnier V, Schnitzler A, Voges J, Nikkhah G, Vesper J, Naumann M, Volkmann J: Pallidal deep-brain stimulation in primary generalized or segmental dystonia. N Engl J Med 2006;355:1978-1990.

9 Vidailhet M, Vercueil L, Houeto JL, Krystkowiak P, Benabid AL, Cornu P, Lagrange C, Tezenas du Montcel S, Dormont D, Grand S, Blond S, Detante O, Pillon B, Ardouin C, Agid Y, Destee A, Pollak P: Bilateral deepbrain stimulation of the globus pallidus in primary generalized dystonia. N Engl J Med 2005;352:459-467.

10 Limousin P, Speelman JD, Gielen F, Janssens M: Multicentre European study of thalamic stimulation in parkinsonian and essential tremor. J Neurol Neurosurg Psychiatry 1999; 66:289-296.

11 Benabid AL, Pollak P, Gao D, Hoffmann D, Limousin P, Gay E, Payen I, Benazzouz A: Chronic electrical stimulation of the ventralis intermedius nucleus of the thalamus as a treatment of movement disorders. J Neurosurg 1996;84:203-214.

12 Hariz GM, Lindberg M, Bergenheim AT: Impact of thalamic deep brain stimulation on disability and health-related quality of life in patients with essential tremor. J Neurol Neurosurg Psychiatry 2002;72:47-52. 
13 Voges J, Hilker R, Botzel K, Kiening KL, Kloss M, Kupsch A, Schnitzler A, Schneider GH, Steude U, Deuschl G, Pinsker MO: Thirty days complication rate following surgery performed for deep-brain-stimulation. Mov Disord 2007;22:1486-1489.

14 Barbuto JE, Scholl RW: Motivation Sources Inventory: Development and validation of new scales to measure an integrative taxonomyofmotivation. PsycholRep 1998;82:10111022.

15 Wishart D: Interactive graphics for cluster analysis, in Gaul W, Locarek-Junge H (eds): Classification in the Information Age. Studies in Classification, Data Analysis and Knowledge Organization. Berlin, Springer, 1999.

-16 Follett KA, Weaver FM, Stern M, Hur K, Harris CL, Luo P, Marks WJ Jr, Rothlind J, Sagher O, Moy C, Pahwa R, Burchiel K, Hogarth P, Lai EC, Duda JE, Holloway K, Samii A, Horn S, Bronstein JM, Stoner G, Starr PA, Simpson R, Baltuch G, De SA, Huang GD, Reda DJ: Pallidal versus subthalamic deepbrain stimulation for Parkinson's disease. N Engl J Med 2010;362:2077-2091.
7 Houeto JL, Bejjani PB, Damier P, Staedler C, Bonnet AM, Pidoux B, Dormont D, Cornu P, Agid Y: Failure of long-term pallidal stimulation corrected by subthalamic stimulation in PD. Neurology 2000;55:728-730.

18 Barcia-Salorio JL, Roldan P, Talamantes F, Pascual-Leone A: Electrical inhibition of basal ganglia nuclei in Parkinson's disease: long-term results. Stereotact Funct Neurosurg 1999;72:202-207.

19 Volkmann J, Allert N, Voges J, Sturm V, Schnitzler A, Freund HJ: Long-term results of bilateral pallidal stimulation in Parkinson's disease. Ann Neurol 2004;55:871-875.

20 Ghika J, Villemure JG, Fankhauser H, Favre J, Assal G, Ghika-Schmid F: Efficiency and safety of bilateral contemporaneous pallidal stimulation (deep brain stimulation) in levodopa-responsive patients with Parkinson's disease with severe motor fluctuations: a 2-year follow-up review. J Neurosurg 1998; 89:713-718.

21 Vegas AA, Jodra VM, Garcia ML: Nosocomial infection in surgery wards: a controlled study of increased duration of hospital stays and direct cost of hospitalization. Eur J Epidemiol 1993;9:504-510.
22 Yao SL, Lu-Yao G: Population-based study of relationships between hospital volume of prostatectomies, patient outcomes, and length of hospital stay. J Natl Cancer Inst 1999;91:1950-1956.

23 Theodosopoulos PV, Ringer AJ, McPherson CM, Warnick RE, Kuntz Ct, Zuccarello M, Tew JM Jr: Measuring surgical outcomes in neurosurgery: implementation, analysis, and auditing a prospective series of more than 5,000 procedures. J Neurosurg 2012, Epub ahead of print.

24 Blomstedt P, Sandvik U, Linder J, Fredricks A, Forsgren L, Hariz MI: Deep brain stimulation of the subthalamic nucleus versus the zona incerta in the treatment of essential tremor. Acta Neurochir (Wien) 2011;153: 2329-2335.

25 Lind G, Schechtmann G, Lind C, Winter J, Meyerson BA, Linderoth B: Subthalamic stimulation for essential tremor: short- and long-term results and critical target area. Stereotact Funct Neurosurg 2008;86:253-258.

26 VanGeest JB, Johnson TP, Welch VL: Methodologies for improving response rates in surveys of physicians: a systematic review. Eval Health Prof 2007;30:303-321. 